\title{
Adaptation and validation of the Organizational Learning Mechanism Scale (OLMS)
}

\section{Adaptação e validação da Escala de Mecanismo de Aprendizagem em Organizações (EMAO)}

GESTÃO PRODUCCÃO

ISSN 0104-530X (Print) ISSN 1806-9649 (Online)

\author{
Fábio Ferreira Silva ${ }^{1}$ (1) \\ Catarina Cecília Odelius ${ }^{1}$
}

\begin{abstract}
How to cite: Silva, F. F., \& Odelius, C. C. (2019). Adaptation and validation of the Organizational Learning
\end{abstract} Mechanism Scale (OLMS). Gestão \& Produção, 26(3), e3428. https://doi.org/10.1590/0104-530X3428-19

\begin{abstract}
The purpose hereof is to adapt the Organizational Learning Mechanism Scale (OLMS), which deals with organizations' actions to create procedures and practices for knowledge acquisition, storage, sharing, and use. The adaptation of this scale was based on the validation of the scale for the Brazilian context, and on a theme-related literature review. The adapted scale was submitted for semantic and theoretical validation by judges and for the application of a pilot test in a small sample. The data of 268 public servants who work in military and civil organizations were collected through electronic means. Once the recommended prior analyses were conducted, we performed a factorial analysis, identifying 3 factors: Internal Acquisition Mechanisms (11 items and $\alpha=0.924)$, Codification and Control Mechanisms ( 8 items and $\alpha=0.899$ ), and External Acquisition Mechanism (3 items and $\alpha=0.726$ ), which explain a total variance of $62.20 \%$, results that were superior to those found in the first adaptation of the OLMS. The final results point to an instrument with good statistical parameters and which is responsible for a great amount of the construct's variance, indicating new directions for the execution of new research.
\end{abstract}

Keywords: Knowledge management; Organizational learning; Organizational human behavior.

\begin{abstract}
Resumo: Este estudo objetiva adaptar a escala Mecanismos de Aprendizagem em Organização (EMAO), a qual trata das ações da organização que visem à criação de procedimentos e práticas para a aquisição, armazenamento, compartilhamento e utilização dos conhecimentos. A escala foi adaptada com base em validação da escala para o contexto brasileiro, e em revisão de literatura relativa ao tema. A escala adaptada foi submetida à validação semântica e teórica por juizes, além da aplicação de um teste piloto em uma pequena amostra. Os dados foram coletados por meio eletrônico junto à 268 servidores públicos que atuam em organizações militares e civis. Após a condução de análises prévias recomendadas, realizou-se a análise fatorial, identificando-se 3 fatores: Mecanismos de Aquisição Interna (11 itens e $\alpha=0,924)$, Mecanismos de Codificação e Controle (8 itens e $\alpha=0$,899) e Mecanismo de Aquisição Interna (3 itens e $\alpha=0,726$ ), os quais explicaram uma variância total de 62,20\%, tendo sido tais resultados superiores aos encontrados na primeira adaptação da EMAO. Os resultados alcançados indicam um instrumento com bons parâmetros estatísticos, além de responder por uma boa quantidade da variância do construto, apontando direções para realização de novas pesquisas.
\end{abstract}

Palavras-chave: Gestão do conhecimento; Aprendizagem organizacional; Comportamento humano nas organizações.

\section{Introduction}

Issues related with organizational knowledge are admittedly relevant, especially when they are considered as a resource of great value for the achievement of organizational goals (Barney, 1991; Penrose, 1959). The perspective of knowledge as an organizational asset becomes a key for the analysis of several variables that coexist in the organizational

environment, and it can affect how agents deal with their daily tensions and organizational performance.

Hartung \& Oliveira (2013) stress that sharing organizational knowledge must be the center of discussions related to understanding knowledge management as an organizational action that would enable us to use knowledge to achieve organizational goals.

\footnotetext{
${ }^{1}$ Programa de Pós-graduação em Administração - PPGA, Universidade de Brasília - UnB, Campus Universitário Darcy Ribeiro, Prédio da Face, CEP 70910-900, Brasília, DF, Brasil, e-mail: fabiosilvaffs96@gmail.com; codelius@gmail.com
}

Received Aug. 26, 2016 - Accepted June 9, 2017

Financial support: None. 
Based on the context of such discussions, we notice increasing debate about environmental nuances that affect organizational knowledge, having as a premise the idea that the organization is an open system that interacts with the environment and is affected by it in the development of organizational learning processes (Lipshitz et al., 2002).

Lipshitz et al. (2002), López et al. (2005), and Isidro-Filho (2009) say that knowledge sharing is affected by learning situations encouraged by the organization called "learning mechanisms", which are defined as institutionalized procedures that are used by the organization to collect, analyze, store, spread, and use ideas that are essential for its performance and that of its members (Isidro-Filho, 2009).

Understanding organizational phenomena requires the development of data collection tools, that is, measurement scales that would allow us to measure them properly. Isidro-Filho (2009), while adapting the scale developed by López et al. (2005), recommended that some of the adapted scale's items should be rewritten to obtain better results, while an analysis of said scale's items indicated the necessity of revising the writing of several items due to the overlapping of some content with the knowledge-sharing construct, underscoring the necessity of giving special attention to the refinement and precision of the research methods employed in management research (Edwards \& Berry, 2010).

The literature review on learning mechanisms and knowledge sharing pointed to a massive concentration of qualitative or quantitative research that mostly used descriptive statistics. In other words, except for the studies presented herein, we noticed a lack of Brazilian studies on the development of scales related to the researched constructs, as well as little use of multivariate statistical methods in the field of the study of the variables. Additionally, since they do not present details regarding the method used, they represent a limited contribution to the knowledge development relating to the subject.

Based on this context, the purpose hereof is to adapt the scale to measure the perception of subjects regarding the learning mechanisms provided by organizations, considering the strategic relevance of the adoption of these actions by the management, to favor knowledge sharing by the subjects within the organizational environment (López et al., 2005; Isidro-Filho, 2009).

The contribution here lies in incrementing and complementing the analysis scope developed in previously validated scales (López et al., 2005; Isidro-Filho, 2009) through the semantic and theoretical review of the items, as well as through the addition of new actions that would represent the establishment of learning mechanisms by the organizations.
To achieve this goal, this paper presents a small theoretical milestone regarding knowledge sharing and learning mechanisms, followed by the characteristics of the scales of López et al. (2005) and Isidro-Filho (2009), the method employed, results, and conclusion.

\section{Theoretical milestone}

The knowledge sharing discussion goes beyond understanding the social aspect of the interaction between subjects in the organizational environment (Hartung \& Oliveira, 2013).

Isidro-Filho (2009) underscores several organizational factors that may affect the acquisition, creation, and sharing of organizational knowledge (Lipshitz et al., 2002). Similarly to Lipshitz et al. (1996, 2002) and Isidro-Filho (2009) develops the understanding of learning mechanisms as the essential aspect for encouraging individual and organizational practices that enable knowledge management activities in the organizational environment.

In the context of this discussion, Lipshitz et al. (2002), López et al. (2005), and Isidro-Filho (2009) adopt a cognitive perspective, in which the learning process consists in allowing the organization to process, interpret, and respond to the information originating from the internal and external environment, enabling it to be consolidated in ways that support the subjects' organizational learning to channel knowledge sharing for the decision-making process.

Isidro-Filho (2009) defines "learning mechanisms" as the creation of procedures and enabling practices that allow the acquisition, analysis, storage, sharing, and use of knowledge. The author therefore attributes similar definitions to learning mechanisms and knowledge management actions, considering the possibility that these mechanisms are understood as stages of this management process.

Under the influence of the work of López et al. (2005) and Isidro-Filho (2009) classifies learning mechanisms as the external and internal acquisition that happens through actions that enable the gathering of relevant knowledge for organizational goals; distribution, which is related to how the knowledge is shared in the organization; interpretation, related to the incorporation and sharing of knowledge, enabling a reading of the environment that supports the decision-making process; and organizational memory, which is related to how the organization stores its knowledge for future use.

Based on the Organizational Learning Mechanism Scale (OLMS) developed by López et al. (2005) and Isidro-Filho (2009) adapts this scale, whose purpose is to collect data on learning mechanisms based on the aforementioned four dimensions: acquisition, distribution, interpretation, and organizational memory. After the translation of the scale by experts and the adoption of criteria to minimize language, ambiguity, 
and bias issues (Gunther, 1999), we got a 22-item adapted scale, which was applied on 522 employees of a financial institution located in Brasília-DF.

The scale's adaptation process, adopted by Isidro-Filho (2009), considered the procedures recommended in the literature to preserve the research tool's validity and trustworthiness (Pasquali, 1997). The rates found in the research show that the Kaiser-Meyer-Olkin (KMO) obtained was $0.92(\mathrm{p}>0.000)$, while the explained variance total was $49.62 \%$. After the factorial analysis, no item presented a factorial load of less than 0.35 for the extracted factors.
The results found by Isidro-Filho (2009) are presented in Table 1.

The 22 items, supported in a 5-point Likert scale (from 1 - it never happens to 5 - it always happens), of the scale of López et al. (2005), adapted by Isidro-Filho (2009), were distributed in a 3 -factor structure, which explained $49.62 \%$ of the total variance of the participants' answers.

The constitution of the scale adapted by Isidro-Filho (2009) is different from the original version created by López et al. (2005) because, while it is composed of 4 factors, the adapted scale has 3 factors, which are

Table 1. OLMS Summary.

\begin{tabular}{lcc}
\hline \multicolumn{1}{c}{ Factor 1 - Internal and External Knowledge Acquisition (alpha = 0.81) } \\
\hline \multicolumn{1}{c}{ Description of the Item } & $\begin{array}{c}\text { Factorial } \\
\text { Load }\end{array}$ & H $^{2}$ \\
\hline $\begin{array}{l}\text { The organization encourages its employees to participate in formal and informal } \\
\text { external networks and groups of people. }\end{array}$ & 0.69 \\
$\begin{array}{l}\text { The organization promotes partnerships with other organizations, universities, technical } \\
\text { schools, etc. }\end{array}$ & 0.63 \\
$\begin{array}{l}\text { The organization keeps itself in touch with external professionals and experts. } \\
\text { The organization promotes and supports innovations. }\end{array}$ & 0.58 & 0.69 \\
$\begin{array}{l}\text { The organization offers learning opportunities, such as internal training programs, visits } \\
\text { to other department, etc. }\end{array}$ & 0.51 \\
$\begin{array}{l}\text { The organization identifies specific experts or subjects through catalogs or e-mails filed } \\
\text { according to the themes to each of which they belong. }\end{array}$ & 0.48 \\
My team members participate in external events (conventions, fairs, symposiums, etc.). & 0.46 & 0.43 \\
\hline
\end{tabular}

\begin{tabular}{|c|c|c|}
\hline \multicolumn{3}{|l|}{ Factor 2 - Knowledge Sharing $($ alpha $=\mathbf{0 . 8 7})$} \\
\hline Description of the Item & $\begin{array}{l}\text { Factorial } \\
\text { Load }\end{array}$ & $\mathbf{H}^{2}$ \\
\hline My team members have the same goal. & 0.65 & 0.61 \\
\hline $\begin{array}{l}\text { My team members share knowledge and experiences through dialogs with other } \\
\text { workmates. }\end{array}$ & 0.62 & 0.69 \\
\hline $\begin{array}{l}\text { My team members collect, classify, and distribute internal suggestions to the other } \\
\text { members. }\end{array}$ & 0.59 & 0.55 \\
\hline Teamwork is a common practice in the organization. & 0.53 & 0.51 \\
\hline New work performance ideas and approaches are daily applied in my team. & 0.50 & 0.49 \\
\hline The employees are informed about the organization's goals. & 0.48 & 0.46 \\
\hline $\begin{array}{l}\text { Meetings are held to inform the employees about the latest innovations in the } \\
\text { organization. }\end{array}$ & 0.47 & 0.49 \\
\hline $\begin{array}{l}\text { The organization develops internal task and employee-change rotation programs } \\
\text { between departments and positions. }\end{array}$ & 0.42 & 0.42 \\
\hline $\begin{array}{l}\text { The organization has formal mechanisms that ensure the sharing of better practices } \\
\text { between different activity fields. }\end{array}$ & 0.41 & 0.55 \\
\hline My team members participate in other teams or units, and work as links between them. & 0.39 & 0.32 \\
\hline \multicolumn{3}{|l|}{ Factor 3 - Knowledge Codification and Control $($ alpha $=\mathbf{0 . 7 1 )}$} \\
\hline Description of the Item & $\begin{array}{l}\text { Factorial } \\
\text { Load }\end{array}$ & $\mathbf{H}^{2}$ \\
\hline The databases used by my team are updated. & 0.73 & 0.68 \\
\hline $\begin{array}{l}\text { The organization's databases are consulted through several types of network (Lotus } \\
\text { Notes, intranet, etc.). }\end{array}$ & 0.61 & 0.59 \\
\hline The organization has an updated client database. & 0.60 & 0.58 \\
\hline The organization has a database to store its experiences and knowledge. & 0.36 & 0.55 \\
\hline
\end{tabular}

Table shows the factorial load and $\mathrm{H}^{2}$ (commonality), which represents the amount of variance explained by the factor solution for each variable. Adapted from "Análise multivariada de dados", by Hair et al. (2010). Source: Isidro-Filho (2009). 
established as follows: Factor 1 - Internal and External Knowledge Acquisition, which was defined as the set of organizational actions towards the search for knowledge in the internal and external environment that enables learning in the organization, presenting a Cronbach's alpha of 0.81 and factorial loads between 0.45 and 0.69 ; Factor 2 - Knowledge Sharing - this was defined as actions based in social exchange relations between the members of a team/organization, in which knowledge and experiences are shared and contribute to the acquisition of new behaviors and attitudes that can positively affect the work performance, with a Cronbach's alpha of 0.87 and items with factorial loads between 0.39 and 0.65 ; finally, Factor 3 - Knowledge Codification and Control was defined as a set of databases for the storage and management of relevant knowledge and experiences that favor the access to and use of these resources by the organization's employees, reaching a Cronbach's alpha of 0.71 and factorial loads between 0.36 and 0.73 .

Isidro-Filho (2009) underscores that, in spite of the elevated Cronbach's alphas reached, the results of the research indicate a possibility of improving some items, to improve their respective factorial loads, which would result in greater trustworthiness, especially in Factor 3 - Knowledge Codification and Control. However, even with the observations pointed out by the author, we can see that this paper deals with the main features of the knowledge management literature, agreeing with the reasoning of authors like Davenport \& Prusak (1998), Probst et al. (2002), Heisig (2009), Xavier et al. (2012) and Hartung \& Oliveira (2013).

\section{Investigation method}

The work presented herein is part of a wider one, in which the group of researched organizations was composed to obtain the greatest variability of possible participants, including civil and military organizations of the Federal Direct Administration, chosen by accessibility.

Military organizations have the obligation of managing the acquisition process of complex defense systems, the coordination of teaching actions, and the dimensioning of the human resource necessity, as well their posterior allocation according to their specific competences. In these organizations, managers and directors were invited to participate, as well as people who execute and observe the regulations and directives established by their superiors.

The group of civil organizations was composed of organizations with obligations and activities related to social policies, according to Ordinance $\mathrm{n}^{\circ} 7.191$, of May 31, 2010. Our intention was to use the same selection method used in the general population, however, due to difficulties in obtaining authorization to apply the research tool in every functional level of these organizations, we chose to limit the population to the Technical Analysts of Social Policies (TASP), considering the possibility of access to this civil servant population.

To adapt the scale, we followed the recommendations made by Isidro-Filho (2009) of creating new items based on the pertaining theory and of submitting the scale to a new semantic validation process, with the purpose of improving the factorial charges and the tool's trustworthiness.

Additionally, all items of the OLMS adapted by Isidro-Filho (2009) were rewritten based on the learning mechanism literature, since in a preliminary analysis, we detected the necessity to readjust every item related to the Knowledge Sharing factor to contextualize the items as an action caused by the organization. Without executing this action, we would have the impression that this factor's items would reflect the knowledge sharing phenomenon itself, and not a condition caused by the organization for its execution.

Then, we began a semantic and theoretical validation process of the items, in which some of the students and teachers of a federal university's Management Post-Graduation Program (MPGP) took part. After this process, we got a new scale, composed of 24 items, that is, 2 items more than the original scale.

The evolution of the suggestions and observations of a semantic and theoretical nature presented enabled the development of a new scale, which was submitted to a small sample of the target audience, with the purpose of verifying if they could be understood by the members of the population to which the tool would be applied and to answer questions that the items might eventually raise.

After this stage, e-mails were sent to the target population, which included an explanatory text about the research, as well as a link that would direct the participant to a survey published in the research platform SurveyMonkey.

The data of 268 participants were collected and submitted to factorial analysis. Tabachnick \& Fidell (2007) indicate that the factorial analysis technique enables us to find the underlying structure of a data matrix to determine the number and nature of its latent variables (factors), which would enable a better representation of the variable set under observation. Before the factorial analysis, we performed a data cleaning and treatment stage, and analyses of absent data, sample size, distribution normality, linearity, and extreme cases (Tabachnick \& Fidell, 2007).

Since multivariate outliers can affect the correlation matrix because they reduce or increase the association magnitude between variables (Pasquali, 2005; 
Tabachnick \& Fidell, 2007; Hair et al., 2010), we chose to exclude such cases from the subsequent analyses, considering that such action would not have a prejudicial effect on the rate of 10 participants per item. Therefore, the adjusted sample had a total of 262 participants for the Learning Mechanism scale.

The factorial analysis was simultaneously processed through the main component analysis with the data factorability analysis through the KMO (Kaiser-Meyer-Olkin) index, Bartlett's test of sphericity, and the percentage of the correlations greater than 0.30 (Tabachnick \& Fidell, 2007).

We should underscore that, unlike the analysis conducted by Isidro-Filho (2009), in which the factor's rotation was performed orthogonally (varimax) and in which the correlation between the factors is supposedly void $(r=0)$, generating factors that are independent from one another (Damásio, 2012), the data gathered here were processed using an oblique rotation, which enabled the correlation of the factors with each other (Schmitt \& Sass, 2011). According to these authors, this technique is more suitable for social science research, considering the difficulty of handling human behavior separately, dividing them into subunits that are independent from one another (Schmitt \& Sass, 2011).

Then we determined the number of factors of the scale based on the quantity of variance explained in each component, the eigenvalue, the screeplot graph, and especially the theoretical meaning of each item group (Tabachnick \& Fidell, 2007). For the factor rotation, we used the main axle method with oblique rotation of the promax type, using the interpretability criterion.

\section{Results}

Factorial analysis of the learning mechanism scale was performed through the main component grouping study. Besides the fact that $74 \%$ of the matrix's correlations values were greater than 0.30 , the data of Table 2 prove the factorability of the correlation matrix based on Bartlett's test of sphericity, and on the KMO index of 0.934, which was considered as excellent (Kaiser, 1974).

As for the number of factors to be extracted, the screeplot graph, the eigenvalues, and the amount of explained variance point to the existence of 4 factors, according to Table 3 .

However, the rotation with four factors did not result in a proper adjustment between the structure presented by the scale and the theoretical referential adopted, ratifying the premise that the application of statistical techniques is presented only as a tool to be used by researchers, while the theoretical relevance of the group continues to be the determining criterion to establish the number of factors (Pasquali, 2005).

Therefore, based on the theoretical referential adopted and on the comparison between the admitted factorial structures when rotated with four or three factors, we chose the solution with three factors.

The analysis of the established factors underscored that the items 1 (The organization encourages its members to participate in external groups and people networks) and 5 (The organization offers learning opportunities, like internal training programs, technical visits to other departments) were included in the Internal and External Acquisition Mechanism factors, respectively. However, we chose to exclude items 1 and 5 because the text thereof was in disagreement with the definition adopted for the constitution of said factors.

Regarding item 1, the word "external" would probably induce the participant to understand that the

Table 2. Factorability of the Learning Mechanism scale.

\begin{tabular}{ccc}
\hline \multicolumn{2}{c}{ Sampling suitability Kaiser-Meyer-Olkin unit } & .934 \\
\hline Bartlett's test of sphericity & Approx. Chi-square & 4102.587 \\
& DF $^{\mathrm{a}}$ & 276 \\
& Sig. $^{\text {b }}$ & 0.000 \\
\hline
\end{tabular}

${ }^{a}$ Degrees of Freedom (DF) is the number of independent determinations (sample size) minus the number of statistical parameters to be evaluated in the population; ${ }^{b} \mathrm{Sig}$. less than 0.05 shows us that the correlation matrix is not an identity matrix, and therefore there are some relationships between the variables expected to be included in the analysis. Table shows the scale factorability through the KMO, chi-square, degree of freedom (Df) and significance. Adapted from "Análise multivariada de dados", by Hair et al. (2010). Source: Research data.

Table 3. Summary of the Learning Mechanism scale's main component analysis.

\begin{tabular}{|c|c|c|c|c|}
\hline \multirow[t]{2}{*}{ Factor } & \multicolumn{3}{|c|}{ Initial proper values } & \multirow{2}{*}{$\begin{array}{c}\begin{array}{c}\text { Rotational sums of } \\
\text { square loads }\end{array} \\
\text { Total }\end{array}$} \\
\hline & Eigenvalue & $\%$ of variance & Cumulative \% & \\
\hline 1 & 10.627 & 44.280 & 44.280 & 10.627 \\
\hline 2 & 2.395 & 9.978 & 54.258 & 2.395 \\
\hline 3 & 1.558 & 6.492 & 60.750 & 1.558 \\
\hline 4 & 1.253 & 5.220 & 65.870 & 1.253 \\
\hline
\end{tabular}

Source: Research data. 
establishment of the network would happen outside the organization, when, in fact, the intention was that this word would suggest the establishment of relationship networks with other persons or sectors of the organization itself. This semantic divergence probably affected the low load assumed by the item in the factor $(0.429)$. We suggest the replication of item 1 in future research, adopting this new text: "The organization encourages its members to participate in people groups and networks in the organization".

Regarding item 5, the word "internal" suggests that the training program occurs inside the organization, when actually the idea was to represent the realization of training programs outside the organization, but with its support. That is, the word "internal" causes a semantic conflict between the learning mechanism mentioned in the item and the definition of the factor "external acquisition mechanism," which caused the exclusion of item 5 .

However, we suggest the use of item 5 in future research to represent the support of the organization as an External Acquisition Mechanism, adopting the suggested new text: "The organization offers learning opportunities, like training programs and technical visits to other organizations".
Consequently, after the exclusion of these two items, the learning mechanism scale was consolidated with 22 items. After this analysis, we performed a new factor extraction with the 22 remaining items, using the main axle method (MAM), with promax rotation. After six iterations, we got the best scale structure after the trustworthiness analysis of each factor through the Cronbach's alpha index.

In summary, the learning mechanism scale was composed of 22 items in its final version, distributed into three factors, which explained a total variance of $62.20 \%$ with only two items with a load under 0.50 .

As for the quality of the items, according to Comrey \& Lee (1992), an excellent item has a load greater than 0.71 , a very good item has a load greater than 0.63 , a good item has a load greater than 0.55 , an average item has a load greater than 0.45 , and a poor item has a load greater than 0.32. As for the trustworthiness of the factors, Pasquali (2005) says that Cronbach's alphas $(\alpha)$ greater than 0.70 are considered trustworthy, while values greater than 0.80 are very trustworthy.

Based on such parameters and on the theoretical structure of the subject, this first factorial analysis allows us to make some reflections. The Internal Acquisition Mechanism factor (Table 4) was presented as responsible

Table 4. Summary of the Internal Acquisition Mechanism factor.

\section{Internal Acquisition Mechanisms}

Set of actions taken by the organization that favors social interaction between individuals in the work environment, so the knowledge and experiences are shared between the members of the internal organizational context.

\begin{tabular}{|c|c|c|c|c|}
\hline Item & Description & $\begin{array}{l}\text { Factorial } \\
\text { Load }\end{array}$ & Quality & $\mathbf{H}^{2}$ \\
\hline 10 & $\begin{array}{l}\text { The organization encourages its members to share suggestions in the } \\
\text { work environment. }\end{array}$ & 0.907 & Excellent & 0.692 \\
\hline 11 & The organization encourages teamwork. & 0.824 & Excellent & 0.674 \\
\hline 4 & $\begin{array}{l}\text { The organization encourages its members to propose new ideas regarding } \\
\text { work subjects. }\end{array}$ & 0.814 & Excellent & 0.608 \\
\hline 12 & $\begin{array}{l}\text { The organization encourages new ideas and approaches on work } \\
\text { performance to be applied daily. }\end{array}$ & 0.803 & Excellent & 0.639 \\
\hline 16 & $\begin{array}{l}\text { The organization informs its members about the responsibilities of other } \\
\text { workmates and departments. }\end{array}$ & 0.757 & Excellent & 0.643 \\
\hline 9 & $\begin{array}{l}\text { The organization creates informal environments in which people can } \\
\text { share knowledge and experiences with workmates. }\end{array}$ & 0.704 & $\begin{array}{l}\text { Very } \\
\text { Good }\end{array}$ & 0.502 \\
\hline 13 & $\begin{array}{l}\text { The organization holds meetings to inform its members about } \\
\text { innovations in its activities. }\end{array}$ & 0.684 & $\begin{array}{l}\text { Very } \\
\text { Good }\end{array}$ & 0.544 \\
\hline 14 & $\begin{array}{l}\text { The organization exchanges professionals between departments and } \\
\text { positions, enabling people to participate in other teams. }\end{array}$ & 0.612 & Good & 0.627 \\
\hline 6 & $\begin{array}{l}\text { The organization identifies people in the organization itself with } \\
\text { expertise in specific subjects through catalogs or any other means of } \\
\text { registration. }\end{array}$ & 0.566 & Good & 0.536 \\
\hline 15 & The organization encourages task rotations between its employees. & 0.560 & Good & 0.679 \\
\hline 17 & $\begin{array}{l}\text { The organization encourages the sharing of work practices between its } \\
\text { several sectors through formal mechanisms (e.g., scheduled meetings, } \\
\text { space in internal network for procedure registration, etc.). }\end{array}$ & 0.461 & Average & 0.607 \\
\hline \multicolumn{3}{|c|}{ Trustworthiness - Cronbach's Alpha } & \multicolumn{2}{|c|}{0.924} \\
\hline \multicolumn{2}{|c|}{ Eigenvalue } & & \multicolumn{2}{|c|}{9.967} \\
\hline \multicolumn{2}{|c|}{ Total Variance } & & \multicolumn{2}{|c|}{45.305} \\
\hline
\end{tabular}

Source: Research data. 
for most of the explained variance, underscoring a strong feature related to the knowledge management action perspective linked to knowledge customization features (Joia \& Oliveira, 2007).

The Internal Acquisition Mechanism factor (Table 4) agrees with the results found by Crossan et al. (1999), and Faoro \& Oliveira (2014), who reported the consolidation of actions within the internal scope of the organization with the purpose of institutionalizing the social interaction between its employees, creating environments that are favorable for the exchange of experiences and knowledge.

Although authors like Lipshitz et al. $(2002,1996)$ underscored the importance of task rotation actions, the consolidation with elevated factorial loads of items that represent this kind of mechanism supports the reasoning of Slater \& Narver (1995), for whom a knowledge-sharing oriented organization must be flexible and capable of relocating its human resources into new organizational designs so as to respond to environmental threats or to seize eventual opportunities.

Mezias et al. (2001), Tonet \& Paz (2006), and Hartung \& Oliveira (2013) underscore that the subjects depend on knowledge sharing for a better decision-making process for the organization's advantage. That is, constituting the Internal Acquisition Mechanism factor is essential to establish the set of actions that will enable interaction between the subjects, through formal or informal means, to share the acquired knowledge within the team (Lim \& Klobas, 2000; Aurum et al., 2008).

The creation of the Codification and Control Mechanism factor (Table 5) agrees with the results found by Yang \& Chen (2007) in their research on the organizational knowledge capability features of a given organization. Yang \& Chen (2007) identified the Technical Knowledge factor as responsible for explaining a significant part of the variance, defining it as the ability to integrate and develop knowledge through the efficient use of information and communication technologies.

The use of codification and control mechanisms is strongly supported for new technologies that support the establishment of processes and actions that allow the coordinated and structured sharing of knowledge (Probst et al., 2002; Alvarenga, 2008).

As for the External Acquisition Mechanism factor (Table 6), Davenport \& Prusak (1998), and

Table 5. Summary of the Codification and Control Mechanism factor.

\section{Codification and Control Mechanisms}

Set of actions taken by the organization that favors the storage, localization, access, and use of the databases and experiences of the subjects for the organization's activities.

\begin{tabular}{|c|c|c|c|c|}
\hline Item & Description & $\begin{array}{l}\text { Factorial } \\
\text { Load }\end{array}$ & Quality & $\mathbf{H}^{2}$ \\
\hline 22 & $\begin{array}{l}\text { The organization employs methods to locate knowledge } \\
\text { stored in the databases. }\end{array}$ & 0.968 & Excellent & 0.746 \\
\hline 23 & $\begin{array}{l}\text { The organization employs methods to update the } \\
\text { available databases. }\end{array}$ & 0.957 & Excellent & 0.739 \\
\hline 21 & $\begin{array}{l}\text { The organization defines policies for the storage of } \\
\text { information and knowledge in databases of some kind of } \\
\text { internal network (e.g., intranet and physical repository of } \\
\text { documents). }\end{array}$ & 0.858 & Excellent & 0.657 \\
\hline 18 & $\begin{array}{l}\text { The organization makes a database available to recover } \\
\text { knowledge on developed activities and processes. }\end{array}$ & 0.723 & Excellent & 0.700 \\
\hline 19 & $\begin{array}{l}\text { The organization establishes in which databases (physical } \\
\text { or virtual) the subjects' specific pieces of knowledge } \\
\text { should be materialized. }\end{array}$ & 0.652 & Very Good & 0.677 \\
\hline 20 & $\begin{array}{l}\text { The organization has a database about other organizations } \\
\text { with which it interacts. }\end{array}$ & 0.640 & Very Good & 0.465 \\
\hline 24 & $\begin{array}{l}\text { The organization encourages lessons learned from the } \\
\text { results of organizational projects to be documented as a } \\
\text { result of important success or due to failures. }\end{array}$ & 0.533 & Average & 0.591 \\
\hline 8 & $\begin{array}{l}\text { The organization allows its internal public to consult the } \\
\text { databases or repository of documents through some kind } \\
\text { of internal network (e.g., intranet). }\end{array}$ & 0.457 & Average & 0.394 \\
\hline \multicolumn{3}{|c|}{ Trustworthiness - Cronbach's Alpha } & \multicolumn{2}{|c|}{0.899} \\
\hline \multicolumn{3}{|c|}{ Eigenvalue } & \multicolumn{2}{|c|}{2.255} \\
\hline \multicolumn{2}{|c|}{ Total Variance } & & \multicolumn{2}{|c|}{10.249} \\
\hline
\end{tabular}

Source: Research data. 
Table 6. Summary of the External Acquisition Mechanism factor.

\section{External Acquisition Mechanisms}

Set of actions taken by the organization that favors the subjects' interaction with the subjects and/or people groups of other organizations whose activities are similar or contribute to the organization that promotes such actions.

\begin{tabular}{|c|c|c|c|c|}
\hline Item & Description & $\begin{array}{l}\text { Factorial } \\
\text { Load }\end{array}$ & Quality & $\mathbf{H}^{2}$ \\
\hline 2 & $\begin{array}{l}\text { The organization promotes partnerships with other organizations, such as } \\
\text { universities, private companies, and NGOs. }\end{array}$ & 0.882 & Excellent & 0.458 \\
\hline 3 & $\begin{array}{l}\text { The organization keeps itself in touch with external professionals and } \\
\text { experts. }\end{array}$ & 0.622 & Good & 0.400 \\
\hline 7 & $\begin{array}{l}\text { The organization provides means for its employees to participate in } \\
\text { external events (e.g., conventions, fairs, and symposia). }\end{array}$ & 0.415 & Average & 0.491 \\
\hline \multicolumn{3}{|c|}{ Trustworthiness - Cronbach's Alpha } & \multicolumn{2}{|c|}{0.726} \\
\hline \multicolumn{2}{|c|}{ Eigenvalue } & & \multicolumn{2}{|c|}{1.463} \\
\hline \multicolumn{2}{|c|}{ Total Variance } & & \multicolumn{2}{|c|}{6.649} \\
\hline
\end{tabular}

Source: Research data.

Table 7. Factor Correlation Matrix of the Learning Mechanism Scale.

\begin{tabular}{cccc}
\hline Factor & $\mathbf{1}$ & $\mathbf{2}$ & $\mathbf{3}$ \\
\hline 1 & 1.000 & .631 & .462 \\
2 & .631 & 1.000 & .312 \\
3 & .462 & .312 & 1.000 \\
\hline
\end{tabular}

Source: Research data.

Probst et al. (2002) talked about the necessity of knowledge acquisition actions in an environment outside the organization. However, Dodgson (1993), Sinkula (1994), and López et al. (2005) go beyond the simple ratification of this necessity.

Dodgson (1993), Sinkula (1994), and López et al. (2005) stress why it is important for organizations to interact proactively with the environment, not only resulting in the acquisition of pieces of knowledge that are necessary for organizational activities, but especially to understand how such knowledge is handled and understood outside the organization's boundaries.

On the other hand, the External Acquisition Mechanism factor ratifies the importance of establishing a relationship with other people groups or organizations, which may result in interaction with other agents, whose eventual favorable and cooperative actions may contribute to solving problems in the organizational environment (López et al., 2005; Isidro-Filho, 2009).

Although the internal consistency of the External Acquisition Mechanism factor was considered good (greater than 0.70 ), we must mention the possibility of developing items that reflect this mechanism, which could increase the amount of variance explained by the factor and consequently result in an improvement of the tool as a whole (Pasquali, 2005).

In a final analysis, the correlation coefficients between the factors indicated considerable correlations (near to 0.5 ), which justifies the adoption of the oblique criterion for the factor rotation (Tabachnick \& Fidell, 2007), according to Table 7 . We must underscore that the pattern matrix (direct effects) were similar to the structure matrix (total effects).

\section{Discussion}

Although the final results were satisfactory, we need to make an analysis of the OLMS regarding the theoretical consistency of the concepts that support it. Pasquali (2005) underscores that the consolidation of a factor cannot be done only with statistical analyses, but it must also be based on its theoretical relevance in the studied context.

The factorial scale of the learning mechanism scale and the delimitation of the three established factors enable us to go deeper and measure theoretical features in discussions such as the relation between knowledge sharing and the actions taken by the organization (Nonaka \& Von Krogh, 2009), the analysis of the organizational features that can affect the creation and maintenance of proper contexts for knowledge sharing (Tsoukas, 2009), and the subject interaction in a training context created by the organization, considering its active and latent components (Argote $\&$ Miron-Spektor, 2011).

Mezias et al. (2001), Tonet \& Paz (2006), and Hartung \& Oliveira (2013) underscore that the subjects depend on knowledge sharing for a better decision-making process for the organization's advantage. That is, constituting the Internal Acquisition Mechanism factor (Table 4) is essential to establish the set of actions that will enable interaction between the subjects, through formal or informal means, to share the acquired knowledge in the team (Lim \& Klobas, 2000; Aurum et al., 2008).

As for the Codification and Control Mechanisms (Table 5), the several conditions mentioned by 
Nonaka et al. (2000), and Von Krogh et al. (2000) constitute the background of the discussion presented by authors like Terra (2001) and Zellmer-Bruhn (2003), Borgatti \& Cross (2003), Nadler et al. (2003), and Tsoukas (2009), who ratify how important the effect of the knowledge management actions is in the organizational environment through learning mechanisms.

Such authors stress that initiatives of the senior management to reduce the physical and social distances within the organization potentialize the knowledge-sharing conditions, such as localization, access, use, and database and subject experience management in benefit of the organization's activities, together with the identification of experts in specific pieces of knowledge in the organization.

Table 6 consolidates the External Acquisition Mechanism factor, ratifying the need to consider the strategic conditions that are external to the organization, that is, the organization must read the internal and external environment in which it is located (Ndlela $\&$ du Toit, 2001; Kim et al., 2003; Tseng, 2008).

Similarly to Probst et al. (2002), Choo (2003) and Batista (2012) underscore that the actions taken by the organization to map the main pieces of knowledge that are necessary to achieve its goals, in which the knowledge "gaps" that need to be filled are indicated, must consider the interaction with the subjects and/or people groups of other organizations whose activities are similar or contribute to the organization that promotes such actions.

In comparison with all other scale development works, regarding the items related to the Internal (Table 4) and External (Table 6) Acquisition Mechanism factors, such items were grouped very similarly to what was proposed by López et al. (2005), and differently from the scale adapted by Isidro-Filho (2009), but without disconnection between the references used in said works, only restricting the environment in which the phenomenon occurs.

Although the items 1 (The organization encourages its members to participate in external groups and people networks) and 5 (The organization offers learning opportunities, like internal training programs, technical visits to other departments) were excluded from this study, we suggest their use in future research, with a revised text, for a deeper analysis of why the given actions have more or less adherence in organizational environments, considering the cultural, commitment, and error tolerance aspects that exist in each organizational environment (Lipshitz et al., 2002).

Finally, Isidro-Filho (2009), Moresi \& Mendes (2010), and Sá et al. (2013), adopting a cognitive perspective, restate the view that the knowledge management actions taken by formal and informal leaders, as well as administration managers, appear as the main factor influencing the creation of procedures and enabling practices that allow the acquisition, analysis, storage, sharing, and use of knowledge in the organization. These authors categorically say that adopting proper managerial actions for process creation and individual learning, as well as enabling systemic mechanisms and structures that deal with the individual, strategic, and operational level, significantly contribute to the creation of conditions to enable knowledge sharing.

\section{Managerial and academic implications}

The discussion and data analyses performed in this investigation give a glimpse of the significant contributions hereof for the analysis and theoretical refinement of the study of the variables selected here.

Regarding the knowledge management actions, the authors included in the theoretical references contributed to reconciling these actions with the "Learning Mechanism" construct, considering that both converge towards the same goal when analyzed in the organizational environment.

Additionally, this "Learning Mechanism" scale study generates the consolidation of a tool with good statistical parameters, besides being responsible for a considerable amount of variance of the construct $(62.20 \%)$. We also highlight that the adaptation of said scale enables the continuation of previous works (López et al., 2005; Isidro-Filho, 2009), ratifying the discussion of the theme in the context of Organizational Studies.

In managerial terms, this research's findings will enable the researched organizations to increment the knowledge managerial actions developed in the three factors of the learning mechanism scale, besides remodeling the constitution thereof. For example, the senior management can spread the mechanisms of codification and control and of external acquisition more effectively, considering their high correlation with the learning mechanism construct, potentializing the scope and effect of these actions. As for other organizations, they can use the adapted and validated scale to diagnose knowledge management related situations and, based on its results, orient their actions.

Finally, the contribution of this investigation lies in incrementing and complementing the analysis scope developed in previously validated scales (López et al., 2005; Isidro-Filho, 2009) through a semantic and theoretical review of the items, as well as through the addition of new actions that can create and increment the managerial action through the establishment of learning mechanisms by the organizations. 


\section{Limitations and ideas for future research}

Reflecting on the results of this research enables us to point out some of the limitations identified, as well as defining an agenda for future research.

The main limitation found in this research is related to the composition of the sample. Although we searched for diversity in the Federal Direct Administration's environment, greater participation by military servants would have affected in some degree the inference of the final results.

If more civil servants of the Ministries had participated, we could have got more general results, encompassing subjects of several hierarchic levels, instead of concentrating on Technical Analyst of Social Policy (TASP) positions.

Another limitation is related to the absence of answers regarding the sample's demographic features. Considering the non-mandatory aspect of the participation in these surveys, the sample's characterization was limited, and it was not possible to deal with other issues that would increase the strength of the analysis, such as time in the current position and the sector in which the participant has worked in the organization.

Although the analysis of the results eventually carries the bias of the participants belonging to public organizations, the work performed was not specifically developed for this kind of organization. That is, the semantic and theoretical development of the items was based on the relevant literature, which encompasses organizations in several sectors of the economy, not restricting application of the tool to the environment of public organizations.

As for other organizations with activities, structures, and designs that are different from those researched herein, we recommend that:

- The results obtained herein are analyzed with some caution;

- It should be ensured that the features related to learning mechanism actions are contextualized according to: type of relationship of the subjects with the organization, cultural aspects involved, organizational structure, as well as any other features that would distinguish a given organization or group from other organizations that will be evaluated.

Therefore, we underscore the possibility that the scale may be applied in different organizations and managerial sectors, and that future authors will be responsible for their eventual adaptations.

Consequently, we suggest there is great scope for conducting research beyond how the phenomenon was treated herein. Some situations that include the relation of the learning mechanisms with the organizations' structure and design, the economic sector (public, private or third sector), and the field of work (primary-agriculture, secondary-industry, or third-services) can increase the analysis power of the phenomenon, allowing the evaluation of different organizational contexts. On the other hand, we can evaluate the motivation and adherence of the subjects before the learning mechanisms with different personal goals, such as the following: (a) to be recognized as an expert on the subject; (b) maybe by a selflessness issue, that is, for the simple satisfaction of helping one's neighbor; (c) on the other hand, there is the possibility that a subject helps someone else expecting something in return, maybe eventual assistance in a future situation; (d) in another situation, the subjects would adhere to such practices due to the reward system established by the managerial policy of the organization's people; (e) or people simply perform such actions because it is recommended by the organization, like a regulation that they must follow.

Additionally, other relationships can be studied using the developed scale, such as the impact of learning mechanisms made available by the organization on subjects with different characteristics; or its effect on the sharing of different kinds of knowledge and the creation of relationship, hierarchy, affection, and commitment networks.

However, as an attempt to expand the analysis on the theme, it is extremely important to give an equal opportunity to every member of the organization to express his/her vision of the phenomenon. Studies focused on samples that include only directors, managers, and administrators obtain the perspective of the people that are most responsible for the establishment of the managerial actions, and do not represent the complex environment composed of other agents, such as employees, interns, and eventual employees.

These possibilities for the handling of variables represent a way to widen the evidence scope and the validity of the proposals on the relation of the learning mechanisms with other variables of the organizational environment, while simultaneously producing new considerations that could affect the understanding and theoretical consolidation of the field.

\section{Conclusions}

The adaptation process of the Learning Mechanism scale resulted in 22 items distributed among the Internal Acquisition Mechanism (11 items and $\alpha=0.924)$, Codification and Control Mechanism ( 8 items and $\alpha=0.899$ ), and External Acquisition Mechanism (3 items and $\alpha=0.726$ ) factors, which explain a total variance of $62.20 \%$ with only two items of load under 0.50 . 
The final results indicate that we obtained a tool with good statistical parameters and that is responsible for a great amount of the construct's variance $(62.20 \%)$. We also highlight that the adaptation of said scale enabled the continuation of previous works (López et al., 2005; Isidro-Filho, 2009), ratifying the discussion of the theme in the context of Organizational Studies.

The consolidation of the factorial structure enables the measurement of a set of organizational actions that can affect the creation of opportunities for the reduction of physical and social distances within the organization (Lipshitz et al., 2002).

We additionally underscore that the research was performed in a public administration environment, but the use of the scale is not limited to public organizations; it can be used in different organizations and managerial sectors, and future authors will be responsible for their eventual adaptation and analysis.

A second finding is related to the possibility of measuring the relation between the actions of the senior management, widely publicized by Lipshitz et al. (1996, 2002), Terra (2001), Heisig (2009), Isidro-Filho (2009) and Amayah (2013), with the Learning Mechanism scale, as well as giving a glimpse of possible relations with other constructs, such as knowledge sharing.

Finally, the adaptation of the OLMS continues the work performed by Isidro-Filho (2009), with the possibility of improving its semantic and theoretical aspects, and consequently its statistical parameters.

\section{References}

Alvarenga, R. C. D., No. (2008). Gestão de Conhecimento em organizações: proposta de mapeamento conceitual integrativo. São Paulo: Saraiva.

Amayah, A. T. (2013). Determinants of knowledge sharing in a public sector organization. Journal of Knowledge Management, 17(3), 454-471. http://dx.doi.org/10.1108/ JKM-11-2012-0369.

Argote, L., \& Miron-Spektor, E. (2011). Organizational learning: from experience to knowledge. Organization Science, 22(5), 1123-1137. http://dx.doi.org/10.1287/ orsc. 1100.0621 .

Aurum, A., Daneshgar, F., \& Ward, J. (2008). Investigating Knowledge Management practices in software development organizations: an Australian experience. Information and Software Technology, 50(6), 511-533. http://dx.doi. org/10.1016/j.infsof.2007.05.005.

Barney, J. (1991). Firm resources and sustained competitive advantage. Journal of Management, 17(1), 99-120. http:// dx.doi.org/10.1177/014920639101700108.

Batista, F. F. (2012). Modelo de gestão do conhecimento para a administração pública brasileira: como implementar a gestão do conhecimento para produzir resultados em benefício do cidadão. Brasília: IPEA.
Borgatti, S. P., \& Cross, R. (2003). A relational view of information seeking and learning in social networks. Management Science, 49(4), 432-445. http://dx.doi. org/10.1287/mnsc.49.4.432.14428.

Choo, C. W. (2003). A organização do conhecimento. São Paulo: Senac.

Comrey, A. L., \& Lee, H. B. (1992). A first course in factor analysis (2nd ed.). Hillsdale: Lawrence Erlbaum Associates.

Crossan, M. M., Lane, H. W., \& White, R. E. (1999). An organizational learning framework: from intuition to institution. Academy of Management Review, 24(3), 522-537. http://dx.doi.org/10.5465/amr.1999.2202135.

Damásio, B. F. (2012). Uso da análise fatorial exploratória em psicologia. Avaliação Psicológica, 11(2), 213-228.

Davenport, T. H., \& Prusak, L. (1998). Conhecimento empresarial: como as organizações gerenciam o seu capital intelectual. Rio de Janeiro: Campus.

Dodgson, M. (1993). Organizational learning: a review of some literatures. Organization Studies, 14(3), 375394. http://dx.doi.org/10.1177/017084069301400303.

Edwards, J. R., \& Berry, J. W. (2010). The presence of something or the absence of nothing: increasing theoretical precision in management research. Organizational Research Methods, 13(4), 668-689. http://dx.doi. org/10.1177/1094428110380467.

Faoro, R. R., \& Oliveira, M. (2014). Compartilhamento do conhecimento intraorganizacional e interorganizacional: empresas do setor de fruticultura. Perspectiva em Gestão \& Conhecimento, 4(1), 98-118.

Gunther, H. (1999). Como elaborar um questionário. In L. Pasquali (Ed.), Instrumentos psicológicos: manual prático de elaboração (pp. 231-258). Brasília: LabPALM.

Hair, J. F., Black, W. C., Babin, B. J., Anderson, R. E., \& Tatham, R. L. (2010). Análise multivariada de dados (7. ed.). Porto Alegre: Bookman.

Hartung, K., \& Oliveira, M. (2013). Communities of practice: creating and sharing knowledge. Revista de Gestão, 20(3), 407-422. http://dx.doi.org/10.5700/rege507.

Heisig, P. (2009). Harmonisation of knowledge management: comparing $160 \mathrm{KM}$ frameworks around the globe. Journal of Knowledge Management, 13(4), 4-31. http:// dx.doi.org/10.1108/13673270910971798.

Isidro-Filho, A. I. (2009). Mecanismos de aprendizagem em organizações: desenvolvimento e validação de uma escala de medida. Revista de Administração Mackenzie, 10(1), 37-57. http://dx.doi.org/10.1590/ S1678-69712009000100003.

Joia, L. A., \& Oliveira, M. F. B. (2007). Personalização ou codificação? Avaliando estratégias de foco em gestão do conhecimento. Organizações \& Sociedade, 14(43), 13-36. http://dx.doi.org/10.1590/S1984-92302007000400001.

Kaiser, H. F. (1974). An index of factorial simplicity. Psychometrika, 39(1), 31-36. http://dx.doi.org/10.1007/ BF02291575. 
Kim, Y. G., Yu, S. H., \& Lee, J. H. (2003). Knowledge strategy planning: methodology and case. Expert Systems with Applications, 24(3), 295-307. http://dx.doi. org/10.1016/S0957-4174(02)00158-6.

Lim, D., \& Klobas, J. (2000). Knowledge management in small enterprises. The Electronic Library, 18(6), 420432. http://dx.doi.org/10.1108/02640470010361178.

Lipshitz, R., Popper, M., \& Friedman, V. J. (2002). A multifacet model of organizational learning. The Journal of Applied Behavioral Science, 38(1), 78-98. http:// dx.doi.org/10.1177/0021886302381005.

Lipshitz, R., Popper, M., \& Oz, S. (1996). Building learning organizations: the design and implementation of organizational learning mechanism. The Journal of Applied Behavioral Science, 32(3), 292-305. http:// dx.doi.org/10.1177/0021886396323004.

López, S. P., Léon, J. M. M., \& Ordás, C. J. V. (2005). Organizational learning as a determining factor in business performance. The Learning Organization, 12(3), 227 245. http://dx.doi.org/10.1108/09696470510592494.

Mezias, J., Grinyer, P., \& Guth, W. D. (2001). Changing collective cognition: a process model for strategic change. Long Range Planning, 34(1), 71-95. http:// dx.doi.org/10.1016/S0024-6301(00)00096-0.

Moresi, E. A. D., \& Mendes, S. P. (2010). Compartilhamento do conhecimento em portais corporativos. Transinformação, 22(1), 19-32. http://dx.doi.org/10.1590/S010337862010000100002 .

Nadler, J., Thompson, L., \& Van Boven, L. (2003). Learning negotiation skills: four models of knowledge creation and transfer. Management Science, 49(4), 529-540. http://dx.doi.org/10.1287/mnsc.49.4.529.14431.

Ndlela, L. T., \& du Toit, A. S. A. (2001). Establishing a knowledge management programme for competitive advantage in an enterprise. International Journal of Information Management, 21(2), 151-165. http://dx.doi. org/10.1016/S0268-4012(01)00007-X.

Nonaka, I., \& Von Krogh, G. (2009). Tacit knowledge and knowledge conversion: controversy and advancement in organizational knowledge creation theory. Organization Science, 20(3), 635-652. http://dx.doi.org/10.1287/ orsc. 1080.0412 .

Nonaka, I., Toyama, R., \& Konno, N. (2000). SECI, Ba and leadership: a unified model of dynamic knowledge creation. Long Range Planning, 33(1), 5-34. http:// dx.doi.org/10.1016/S0024-6301(99)00115-6.

Pasquali, L. (1997). Psicometria: teorias e aplicações. Brasília: Universidade de Brasília.

Pasquali, L. (2005). Análise fatorial para pesquisadores. Brasília: LabPAM.

Penrose, E. T. (1959). The theory of the growth of the firm. New York: Oxford University Press.

Probst, G., Raub, S., \& Romhardt, K. (2002). Gestão do conhecimento: os elementos constitutivos do sucesso. Porto Alegre: Bookman.
Sá, F. B., Bento, K. G. R., Ziviani, F., \& Ferreira, M. A. T. (2013). Práticas de gestão do conhecimento: um estudo em organizações mineiras. Perspectivas em Gestão \& Conhecimento, 3(1), 114-131.

Schmitt, T. A., \& Sass, D. A. (2011). Rotation criteria and hypothesis testing for exploratory factor analysis: implications for factor pattern loadings and interfactor correlations. Educational and Psychological Measurement, 71(1), 95-113. http://dx.doi.org/10.1177/0013164410387348.

Sinkula, J. M. (1994). Market information processing and organizational learning. Journal of Marketing, 58(1), 35-45. http://dx.doi.org/10.1177/002224299405800103.

Slater, S., \& Narver, J. (1995). Market orientation and the learning organization. Journal of Marketing, 59(3), 6374. http://dx.doi.org/10.1177/002224299505900306.

Tabachnick, B. G., \& Fidell, L. S. (2007). Using multivariate statistics (5th ed.). New York: Harper \& Row Collins College Publishers.

Terra, J. C. C. (2001). Gestão do conhecimento: aspectos conceituais e estudo exploratório sobre as práticas de empresas brasileiras. In M. T. L. Fleury \& M. M. Oliveira, Jr. (Eds.), Gestão estratégica do conhecimento: Integrando aprendizagem, conhecimento e competências (pp. 212-241). São Paulo: Atlas.

Tonet, H. C., \& Paz, M. G. T. (2006). Um modelo para o compartilhamento do conhecimento no trabalho. Revista de Administração Contemporânea, 10(2), 75-94. http:// dx.doi.org/10.1590/S1415-65552006000200005.

Tseng, S. M. (2008). Knowledge management system performance measure index. Expert Systems with Applications, 34(1), 734-745. http://dx.doi.org/10.1016/j. eswa.2006.10.008.

Tsoukas, H. (2009). A dialogical approach to the creation of new knowledge in organizations. Organization Science, 20(6), 941-957. http://dx.doi.org/10.1287/ orsc. 1090.0435 .

Von Krogh, G., Ichijo, K., \& Nonaka, I. (2000). Enabling knowledge creation: how to unlock the mystery of tacit knowledge and release the power of innovation. New York: Oxford University Press. http://dx.doi. org/10.1007/978-1-349-62753-0.

Xavier, L. A O. P., Oliveira, M., \& Teixeira, E. K. (2012). Teorias utilizadas nas investigações sobre gestão do conhecimento. Revista Ibérica de Sistemas e Tecnologia da Informação, 10(10), 1-17. http://dx.doi.org/10.4304/ risti.10.1-18.

Yang, C., \& Chen, L. C. (2007). Can organizational knowledge capabilities affect knowledge sharing behavior? Journal of Information Science, 33(1), 95-109. http://dx.doi. org/10.1177/0165551506068135.

Zellmer-Bruhn, M. E. (2003). Interruptive events and team knowledge acquisition. Management Science, 49(4), 514-528. http://dx.doi.org/10.1287/mnsc.49.4.514.14423. 